\title{
SOME GHANAIAN HERBAL BLOOD TONICS AS SOURCES OF IRON AND OTHER TRACE ELEMENTS (Cu, Zn, Mn, Cd, Pb)
}

\author{
E. Adei, L. Nunoo, and E. Yankey \\ Department of Chemistry, \\ Kwame Nkrumah University of Science and Technology, Kumasi, Ghana
}

\begin{abstract}
Iron deficiency anaemia constitutes about 80 percent of all anaemia cases in developing countries. In Ghana, the 2003 Demographic and Health Survey reported anaemia prevalence of $67 \%$ for urban residents. Anaemia and loss of appetite are the common indications included in the consumer information on the labels on bottles of the numerous Ghanaian herbal blood tonics sold in retail pharmacy and chemical shops. In this study, ten brands of commonly advertised herbal blood tonics on the Ghanaian market were assessed for the levels of iron and other trace elements, wavelength of maximum absorption (2max), pH, salinity and total dissolved solids (TDS). These physico-chemical parameters were determined using a UNICAM 929 atomic absorption spectrophotometer, CECIL 8000 uv-visible spectrophotometer, JENWAY 3020 pH meter and LF538 conductivity meter. Maximum estimated daily dosages of less than $1 \mathrm{mg} /$ day of iron was obtained for all the herbal tonics, except the Madam Catherine brand which had $2.17 \mathrm{mg}$, compared with the required daily intake of $10-15 \mathrm{mg}$. The tonics also appear to be poor sources of the essential metals determined. Cd was detected in Adutwumwaa, Madam Catherine and Top tonics, while Pb was detected in Amingya iron tonic and Madam Catherine; but the levels of these toxic metals will not exceed the recommended safety standards, if the manufacturer's dosages are adhered to.
\end{abstract}

Keywords: Iron-deficiency anaemia, herbal tonics, herbal remedies, toxic metals, .

\section{INTRODUCTION}

The popularity of Ghanaian herbal blood tonics could be seen in the incredible number of these products found in chemical shops, and increasingly, on shelves of a large number of retail pharmacy shops in Ghana. This trend may be due to the affordability of these products and the aggres- sive advertising campaign on the claims of potency of these tonics by manufacturers; using delivery/retail vans with public address systems in the market places and electronic and print media. The common indications that run through Ghanaian herbal blood tonics, which are not used 
to treat specific illness, are anaemia and loss of appetite.

Iron deficiency anaemia, afflicts about two-thirds of children and women of child-bearing age in developing nations (West, 1996). Ghana Demographic and Health Survey (2003) reported 67\% anaemia prevalence for urban residents. Current estimates for anaemia in developing and developed countries respectively are: for pregnant women, 56 and 18\%; school children, 53 and 9\%; preschool children, 42 and 17\%; and men, 33 and $5 \%$ (WHO, 2000). The WHO has suggested the following classification of countries with respect to the level of public health significance of anaemia: a prevalence of $<15 \%$ is "low", $15-40 \%$ is "medium" and $>40 \%$ is "high" (ACC/SCN, 2001). Iron deficiency anaemia, which constitutes about $80 \%$ of all anaemia cases, affects majority of individuals in many developing countries because the diets in these countries are largely vegetarian. The vegetarian diet is not by choice but because meat, poultry, fish etc., with high iron (haeme iron) are too expensive for most people to afford (Yip and Dallman, 1996).

Blood loss caused by heavy menstrual blood flow, intestinal and blood-borne parasitic infections and malaria are other common causes of anaemia among poor populations (Okochi et al., 2003; ACC/SCN, 2001).

The consequences of severe iron deficiency are decreased learning ability, stamina/work performance, and resistance to disease. However, many people with mild iron deficiency experience no obvious problems, other than vague symptoms of tiredness, headache, irritability, or depression. Iron-deficiency anaemia is also accompanied by high morbidity and mortality especially among children aged two years and below and among pregnant women (Wardlaw, 1999).

The adult recommended daily intake (RDI) for iron is $10 \mathrm{mg} /$ day for men and $15 \mathrm{mg} /$ day for women (Ivery and Elmen, 1986). However, where dietary sources of iron are not enough for the management of iron deficiency anaemia, me- dicinal forms of iron, such as ferrous sulphate, need to be ingested. In adults, 150 to $200 \mathrm{mg} /$ day of iron for 4 to 6 months is usually the initial treatment dose, and $3 \mathrm{mg} / \mathrm{kg}$ body weight per day is usually a starting point for infants (Ivery and Elmen, 1986).

Most literate consumers of the herbal medicine who are dissatisfied with modern healthcare system equate "natural" with "safe." Generally, evidence supporting an image of safety of herbal medicine is normally based on an apparent absence, even after prolonged use, of reported adverse effects or harmful constituents (Hegarty and Hegarty, 2001).

The safety, efficacy and quality control of herbal medicinal products are of major concern for governments, consumers, manufacturers and physicians. In Ghana, the Food and Drugs Board (FDB) is empowered by law to ensure that herbal medicines are safe, of good quality and effective (Ministry of Health, 2004). With respect to safety, what has raised concern are contaminants such as synthetic pharmaceuticals (especially prohibited ones), heavy metals, pesticides, fumigation agents, microbial toxins, micro-organisms, toxic botanicals and animal substances (De Smet, 1999). However in respect of efficacy data for product registration, only evidence of long use with minimum side effects is required (Ivery and Elmen, 1986).

Some attempts have been made in assessing the status of trace elements in medicinal plants (Lesniewicz et al, 2006; Divrikli et al, 2006; Ajasa et al., 2004; Serfer-Armah et al., 2002; and Varitika et al., 2001; Abou-Arab et al., 1999; and Kabelitz, 1998). Standardization of herbal medicines is the best guarantee that a product contains what it is supposed to contain in amounts sufficient to produce desired effects. However, the lack of national standards complicates the assessment of the safety and effectiveness of herbal preparations. There is therefore, the need for specifications regarding the efficacy, quality and safety of Ghanaian herbal products, setting up of 
appropriate pharmacopoeia, development of baseline data on quality and "fingerprints" of Ghanaian herbal preparations.

This study will assess some of the advertised/used herbal blood tonics on the Ghanaian market to ascertain whether or not the estimated daily iron ingested using manufacturers' dosage recommendations merit their use in the treatment of iron deficiency anaemia. The levels of essential metals (zinc, copper, magnesium and manganese) in the tonics, extent of toxic heavy metal contamination (cadmium and lead) and the characteristic uvvisible spectra and other physical parameters as "finger-prints" for the tonics will also be determined.

\section{MATERIALS AND METHODS}

\section{Sample collection}

Ten brands of commonly advertised/used herbal blood tonics in 250-350 ml bottles sold on the Ghanaian market were obtained for this study from chemical shops, retail pharmacy shops and delivery vans in Kumasi, Ghana. The tonics were Abrewa Bebobosl, Adutwumwaa, Amingya iron tonic, Blowman tonic, Class tonic, Fralena tonic, Hayaat, Madam Catherine, Mighty Power, and Top tonic. Two over-the- counter iron supplements, Supervitone and Vatalife tonic were also analyzed for comparison. Table 1 gives the ingredients and indications (as stated on the labels on the bottles) of the Ghanaian herbal tonics used in this work.

Table 1: Composition and indications on the labels on the bottles of tonics

\begin{tabular}{|c|c|c|}
\hline Sample & Ingredients & Indications \\
\hline $\begin{array}{l}\text { Abrewa Bebo } \\
\text { bəol }\end{array}$ & $\begin{array}{l}\text { Anthocleista nobilis, Combretodendron } \\
\text { macrocarpus, Khaya senegalensis, Rici- } \\
\text { nodenron heudelotil, Sorghum bicolor }\end{array}$ & $\begin{array}{l}\text { Rheumatism, anaemia, menstrual disorder, } \\
\text { loss of appetite, general disorder, piles and } \\
\text { fever. }\end{array}$ \\
\hline Adutwumuwaa & Mahogany, honey, fruits and vitamins & $\begin{array}{l}\text { Loss of appetite, general weakness and anae- } \\
\text { mia. }\end{array}$ \\
\hline $\begin{array}{l}\text { Amingya Iron } \\
\text { Tonic }\end{array}$ & $\begin{array}{l}\text { Terminalia ivorensis }-25 \%, \text { Anthocleista } \\
\text { nobilis }-30 \% \text {, Khaya ivorensis }-15 \%, \\
\text { Pycenthus angolensis }-20 \%\end{array}$ & $\begin{array}{l}\text { Protect, restore and maintain excellent and } \\
\text { active iron mineral in the blood; recom- } \\
\text { mended for pregnant women, children, adults, } \\
\text { stroke patients and elders. }\end{array}$ \\
\hline $\begin{array}{l}\text { Blowman } \\
\text { Tonic }\end{array}$ & $\begin{array}{l}\text { Khaya senegalensis, Clausena anisata } \\
\text { Xylopia aethiopica, Aframum melegueta, } \\
\text { Ziginber officinale, Monodora myristica }\end{array}$ & $\begin{array}{l}\text { Anaemia, asthmatic condition, blood purifica- } \\
\text { tion. }\end{array}$ \\
\hline Class Tonic & $\begin{array}{l}\text { Khaya senegalensis, Kigelia africana, } \\
\text { Monodora myrustica, preservative }\end{array}$ & $\begin{array}{l}\text { Loss of appetite, anaemia and general body } \\
\text { weakness. }\end{array}$ \\
\hline Fralena & $\begin{array}{l}\text { Khaya Ivorensis, Ficus Capensis, } \\
\text { Pycenthus angolensis }\end{array}$ & Anaemia and loss of appetite. \\
\hline Hayaat & $\begin{array}{l}\text { Terminal ivorensis, Cassia alata, Khaya } \\
\text { ivorensis, Engemia species, Aframimum } \\
\text { malegeta, honey }\end{array}$ & $\begin{array}{l}\text { Anaemia, malnutrition, rheumatism, bodily } \\
\text { pains, loss of appetite, menstrual disorder and } \\
\text { general weakness. }\end{array}$ \\
\hline $\begin{array}{l}\text { Madam } \\
\text { Catherine }\end{array}$ & $\begin{array}{l}\text { Carica papaya, Musa sapientum, Glycine } \\
\text { max, sucrose, molasses, belladonna, sepia, } \\
\text { Nat mur and natural mint }\end{array}$ & $\begin{array}{l}\text { A safe naturopathic preparation extracted } \\
\text { from vegetables, fruits herbs other natural } \\
\text { resources, containing iron, multivitamins, } \\
\text { minerals, glucose, electrolytes, and other heal } \\
\text {-giving homeopathic therapy for cases of } \\
\text { anaemia, malnutrition, menstrual disorder, } \\
\text { loss of appetite, pregnancy, convalescence, } \\
\text { malaria, fevers and general debility }\end{array}$ \\
\hline
\end{tabular}

78 Journal of Science and Technology, Vol. 29, No. 1, April, 2009 
Table 1: Composition and indications on the labels on the bottles of tonics. Cont'd

\begin{tabular}{|c|c|c|}
\hline Sample & Ingredients & Indications \\
\hline Mighty Power & $\begin{array}{l}\text { Black cohosh root }-17 \% \text {, Red ginseng root }- \\
11 \% \text {, Rosemary }-5 \% \text {, Ginger - } 2 \% \text {, Pure honey - } \\
30 \% \text {, Purified water }-35 \%\end{array}$ & $\begin{array}{l}\text { Sexual weakness, waist and back } \\
\text { pains, hair loss, blood purification, } \\
\text { poor vision, dizziness and numbness. }\end{array}$ \\
\hline Supervitone $^{+}$ & $\begin{array}{l}\text { Vitamin } B_{1}-1.5 \mathrm{mg}, \text { Vitamin } B_{2}-0.75 \mathrm{mg}, \\
\text { Vitamin } B_{4}-2.25 \mathrm{mg}, \text { Vitamin } B_{12}-0.0075 \mathrm{mg} \text {, } \\
\text { Vitamin } C-22.5 \mathrm{mg} \text {, Vitamin } \mathrm{D}-3 \mathrm{mg}, \text { Ferrous } \\
\text { Fumarate }-45 \mathrm{mg} \text {, Dessicated liver extract }-15 \\
\mathrm{mg} \text {, Calcium Gluconate }-75 \mathrm{mg}\end{array}$ & $\begin{array}{l}\text { Rich tonic syrup for vitality and } \\
\text { energy. }\end{array}$ \\
\hline Top Tonic & Dumdum, Mahogany, Nyamedua & $\begin{array}{l}\text { Anaemia, purification of blood, } \\
\text { Menstrual disorder, gonorrhea and } \\
\text { body itching. }\end{array}$ \\
\hline Vitalife Tonic $^{+}$ & $\begin{array}{l}\text { Vitamin } \mathrm{B}_{1} \mathrm{BP}-5.0 \mathrm{mg} \text {, Vitamin } \mathrm{B}_{2} \mathrm{BP}-2.0 \\
\mathrm{mg} \text {, Vitamin } \mathrm{B}_{6} \mathrm{BP}-2.2 \mathrm{mg} \text {, Nicotinamide }- \\
20.0 \mathrm{mg} \text { Calcium Pantothenate BP }-10.0 \mathrm{mg} \text {, } \\
\text { Sodium Glycerolphosphate solution } 50 \%-60.0 \\
\text { mg, Magnesium sulphate }-4.0 \mathrm{mg} \text { Ferric Ammo- } \\
\text { nium citrate BP } 50.0 \mathrm{mg} \text {, Citric Acid BP - } 57.0 \\
\text { mg, Liver extract BP }-0.52 \mathrm{ml}\end{array}$ & Anaemia \\
\hline
\end{tabular}

\section{Reagents}

All reagents used were of analytical reagent grade (BDH Chemicals Ltd, Poole, England). Double distilled water was used for preparation of all solutions. The metal standard solutions used for the calibration were prepared by diluting stock (BDH) solutions of $1000 \mathrm{mgL}^{-1}$ of $\mathrm{Fe}, \mathrm{Mn}, \mathrm{Cu}$, $\mathrm{Mg}, \mathrm{Zn}, \mathrm{Cd}$ and $\mathrm{Pb}$.

\section{Herbal tonic samples preparation and diges- tion}

The bottles of herbal blood tonics were shaken thoroughly before they were opened and used. Aliquots of the samples were taken and digested promptly. Ten (10) $\mathrm{ml}$ of each sample was pipetted into a $50 \mathrm{ml}$ beaker and $25 \mathrm{ml}$ of concentrated nitric acid was added slowly. After swirling gently, $3 \mathrm{ml}$ of perchloric acid was added to it and the mixture was heated at $100^{\circ} \mathrm{C}$ until it turned clear (in 30 minutes). The beaker containing the colourless solution was then removed and cooled. The content of the beaker was carefully trans- ferred into a $50 \mathrm{ml}$ volumetric flask and diluted to the mark with distilled water, for subsequent determination of metal ( $\mathrm{Fe}, \mathrm{Mn}, \mathrm{Cu}, \mathrm{Mg}, \mathrm{Zn}, \mathrm{Cd}$ and $\mathrm{Pd}$ ) concentration levels. For each run, a duplicate sample, and a blank were carried through the same procedure.

\section{Chemical and physical analysis of herbal tonic samples}

A UNICAM 929 atomic absorption spectrophotometer (AAS) was used to determine the metal (Fe, Mn, $\mathrm{Cu}, \mathrm{Mg}, \mathrm{Zn}, \mathrm{Cd}$ and $\mathrm{Pd}$ ) concentrations by direct aspiration of the digested sample solutions into the air/acetylene flame. The blanks and calibration standard solutions were also analysed as the digested sample solutions, and calibration curves constructed. The $\mathrm{pH}$ meter, JENWAY 3020 model was calibrated and used for $\mathrm{pH}$ determination of the freshly opened samples. The Conductivity meter LF538 was calibrated and used in the determination of total dissolved solid (TDS), conductivity, salinity and temperature of the 
freshly opened samples. Samples were taken in duplicate. The UV-Visible scan was carried out on freshly opened samples in diluted sample to water ratio of $0.5 \mathrm{ml}: 100 \mathrm{ml}$ using a CECIL 8000 UV-Visible Spectrophotometer.

\section{Determination of recovery}

The recovery test of the analytical procedure was performed for some of the investigated metals (cadmium and zinc) in selected samples by spiking analysed samples with aliquots of metal (BDH) standards and then digested. The sample solutions were then analyzed by AAS. Acceptable recoveries (>85 percent) were obtained for the analyte ions.

\section{RESULTS AND DISCUSSION}

All the herbal tonics studied contained $\mathrm{Fe}, \mathrm{Mg}$, $\mathrm{Mn}, \mathrm{Zn}$ and $\mathrm{Cu}$, which are essential elements needed by the human body (Ivery and Elman, 1986). Table 2 shows concentrations of iron and other trace metals in the blood tonics, and it appears that generally, the different batches of the same herbal tonic had comparable elemental composition. The iron levels found in Supervitone and Vatalife (Table 2), which are between 15 - 131 times that of the herbal tonics, are characteristic of over the counter blood tonics. Figure 1 and Table 3 present the maximum daily intake of the elements calculated on the basis of their levels in the products and their recommended dosage of the herbal products (Table 2).

The major function of iron is formation of haemoglobin and other key compounds used for respiration. Iron is needed for immune function and it also plays a role in drug-detoxification pathways (Ivery and Elman, 1986). In this work the amount of iron from the herbal blood tonics that might be ingested by consumers based on the manufacturers' recommended dosages were estimated to be between $0.43 \mathrm{mg} /$ day for Fralena and $2.17 \mathrm{mg} /$ day for Madam Catherine (Table 3). Thus using an RDI of $10 \mathrm{mg} /$ day, the herbal products had estimated iron of 5 - 23 times below the recommended daily intake (RDI). Due to the likely non compliance that will occur as a result of the $2-3$ tablespoonfuls, 3 times daily dosage, the estimated iron intake from these herbal tonics in Table 3, appears to be a reasonable upper limit. There is therefore no basis for Amingya iron tonic (Table 3) to be labelled as such. Iron absorption in phytotherapeutic treatment of anaemia is less effective than that of animal source (haeme iron), which makes the use of these herbal tonics (non haeme source) in the treatment of iron deficiency anaemia less efficacious. However, plants' sources have the advantage of being usually accompanied by minerals, and many vitamins, including organic acids such as vitamin $\mathrm{C}$ which promotes the absorption of the non-haeme iron in vegetables by reducing $\mathrm{Fe}^{3+}$ to $\mathrm{Fe}^{2+}$ and the subsequent chelation (Ivery and Elman, 1986).

The significantly low iron levels in these Ghanaian herbal tonics used in treating anaemia are not peculiar, because, Chinese prescribed herbal tonics for blood loss are also poor in iron (Dharmananda, 2003); despite the general popularity and acceptance of Chinese herbs. This does not suggest that herbs cannot be rich sources of iron, because spirulina, which is a vegetable, is especially rich in iron, with $5.3 \mathrm{mg}$ per $100 \mathrm{~g}$ of edible product which compares with $2-3$ and 11 mg per $100 \mathrm{~g}$ contained in meat and liver respectively. Availability of iron from spirulina fed to rats is comparable to rats being fed standard ferrous sulphate (Kapoor et al., 1993).

A study of the effects of diet preparation of Telfaria occidentalis on some haematological indices of male albino rats (Okochi et al., 2003) showed dose-dependent increases in all the measured haematological indices (packed cell volume, haemoglobin concentration, red and white blood cell counts). Tetteh (1997) in an 84-day haematological and histopathological studies on rabbits also found Madam Catherine, one of the herbal blood tonics in this work, to be haematinic and nontoxic. Consequently, the low levels of iron found in Madam Catherine in this study suggest the possible role of some organic constituents of these herbal blood tonics, in the stimulation of blood production. 


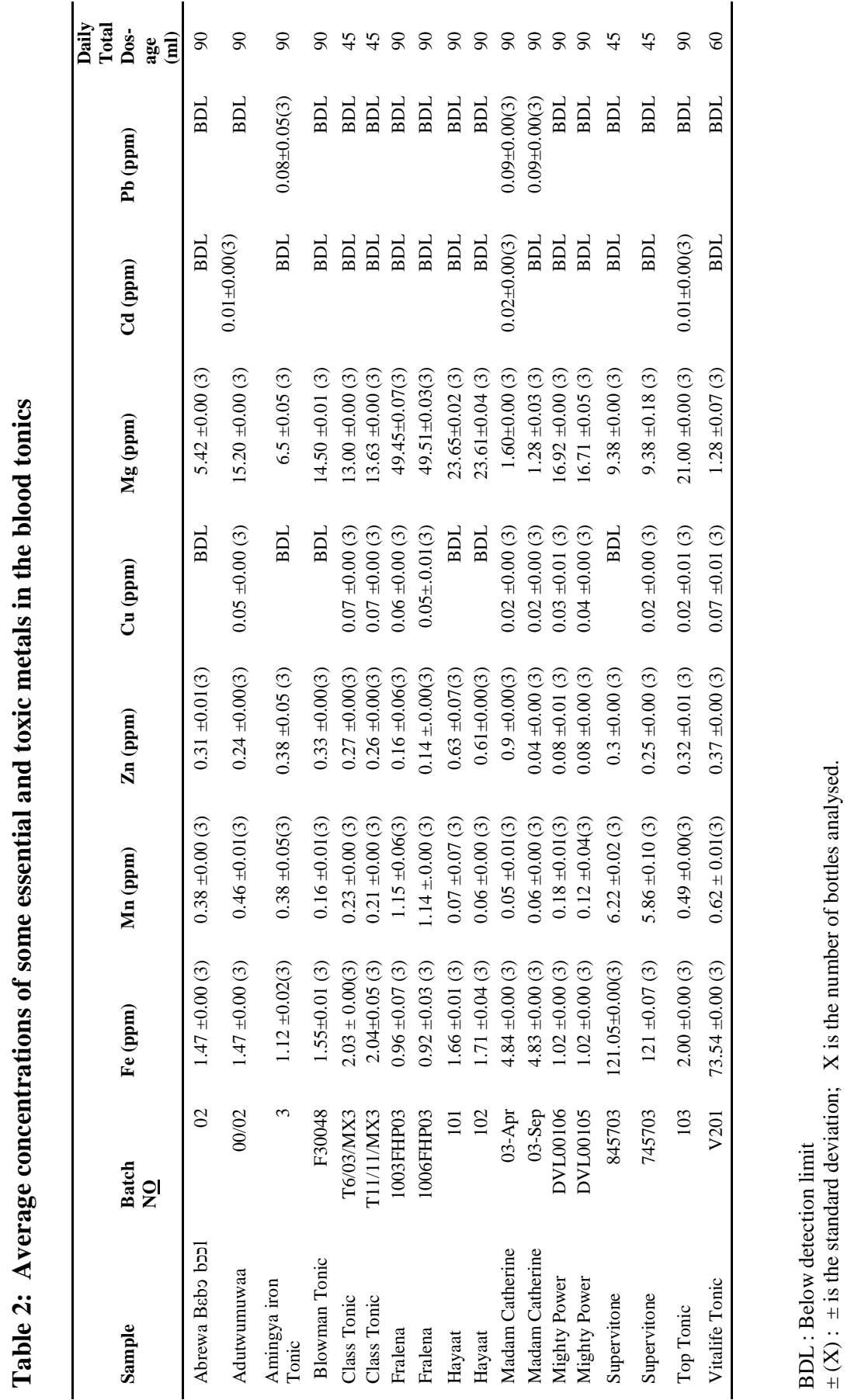


The first line of conventional treatment of iron deficiency anaemia is through the oral treatment with medicinal forms of ferrous salts such as ferrous sulphate, fumarate and gluconate, at initial adult dosages of 150 to $200 \mathrm{mg} / \mathrm{day}$. Consequently, the use of the herbal tonics by local people for the treatment of iron-deficiency anaemia may not be appropriate since the iron levels found

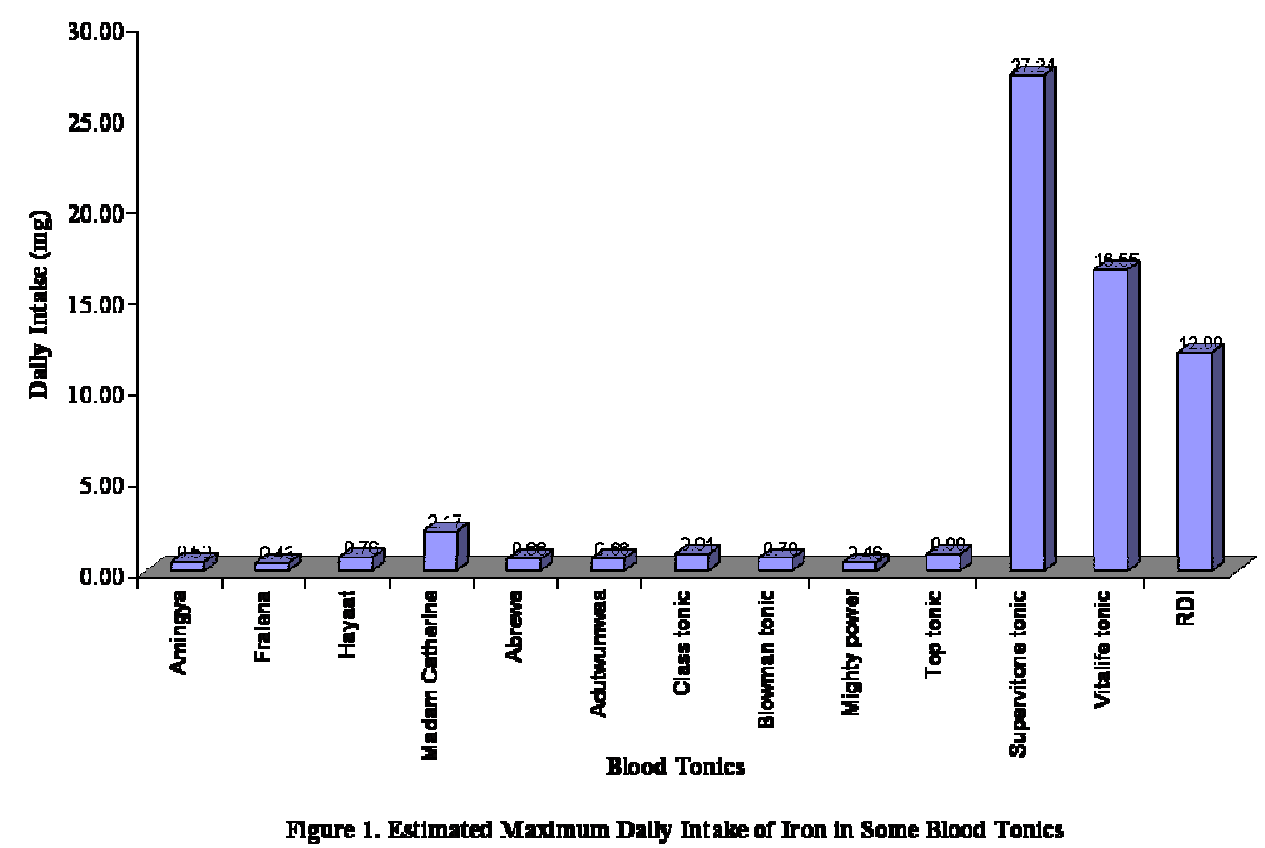

Table 3: Estimated daily intake of essential and toxic metals in blood tonics (mg/daily)

\begin{tabular}{lccccccc}
\hline Sample & $\mathbf{F e}$ & $\mathbf{M n}$ & $\mathbf{Z n}$ & $\mathbf{C u}$ & $\mathbf{M g}$ & $\mathbf{C d}$ & $\mathbf{P b}$ \\
\hline Abrewa Bebəbəol & 0.66 & 0.17 & 0.14 & BDL & 2.44 & BDL & BDL \\
Adutwumwaa & 0.66 & 0.21 & 0.11 & 0.02 & 6.84 & 0.004 & BDL \\
Amingya iron tonic & 0.50 & 0.17 & 0.17 & BDL & 2.92 & BDL & 0.04 \\
Blowman tonic & 0.70 & 0.07 & 0.15 & BDL & 6.52 & BDL & BDL \\
Class tonic & 0.91 & 0.05 & 0.12 & 0.02 & 2.92 & BDL & BDL \\
Fralena & 0.43 & 0.52 & 0.07 & 0.03 & 22.25 & BDL & BDL \\
Hayaat & 0.76 & 0.03 & 0.27 & BDL & 17.19 & BDL & BDL \\
Madam Catherine & 2.17 & 0.02 & 0.40 & 0.01 & 0.72 & 0.01 & 0.04 \\
Mighty power & 0.46 & 0.08 & 0.04 & 0.01 & 7.61 & BDL & BDL \\
Supervitone tonic & 27.24 & 1.40 & 0.07 & 0.01 & 2.09 & BDL & BDL \\
Top tonic & 0.90 & 0.22 & 0.14 & 0.01 & 9.45 & 0.004 & BDL \\
Vitalife tonic & 16.55 & 0.14 & 0.08 & 1.59 & 0.28 & BDL & BDL \\
RDI & $10-15$ & $2-5$ & $12-15$ & $1.5-3.0$ & $280-350$ & 0.06 & 0.21 \\
\hline
\end{tabular}

RDI: Required daily intake

BDL: Below detection limit

+ Over the counter iron supplement 
were too low, compared with the recommended levels. The elderly often experience decreased production of stomach acid, which can lower their iron absorption (Wardlaw, 1999). Thus, it appears that the elderly who suffer from iron deficiency are not likely to benefit from phyto-therapeutic treatment with these herbal tonics.

Magnesium which is an important mineral in connection with circulatory diseases and calcium metabolism in the bone is the element of the highest concentration in all the herbal tonics. Its estimated intake ranged from $0.72 \mathrm{mg} /$ day for Madam Catherine to $22.25 \mathrm{mg} /$ day for Fralena. Generally, the levels of magnesium found in the tonics confirm the herbal nature of the tonics, since magnesium is found mostly in the plant pigment chlorophyll, an important $\mathrm{Mg}$-complex used during photosynthesis in plants. However, these apparently high concentrations of $\mathrm{Mg}$ were generally found to be below $8 \mathrm{mg} /$ day (except in Fralena and Hayaat which are estimated to be above $17 \mathrm{mg} /$ day) and do not meet the RDI of 280 - $350 \mathrm{mg} /$ day. Zinc functions as a cofactor for more than 300 enzymes that are important for growth, sexual development, immune function, wound healing, and taste sensation (Prasad, 1995). The estimated zinc intake of $0.04-0.40$ $\mathrm{mg} /$ day in the herbal tonics is far below 12-15 $\mathrm{mg}$ /day RDI. Copper which aids iron metabolism, and manganese which aids the action of some enzymes such as those involved in carbohydrate metabolism and bone formation, appears to be low in the herbal tonics, with estimated intake of below detection limit and $0.03 \mathrm{mg} / \mathrm{day}$, and 0.02 $-0.52 \mathrm{mg} /$ day for copper and manganese respectively (Table 3 ). These concentrations of copper and manganese are very low, compared with the RDIs of $1.5-3.0 \mathrm{mg} /$ day and $2.0-5.0 \mathrm{mg} /$ day respectively.

Lead and cadmium accumulate in body tissue because the body excretes them slowly (Hamilton and O'Flaherty, 1995; Godt et al., 2006). The presence of cadmium and lead in herbal remedies can pose clinically relevant problems (De Smet, 1999). Cadmium has been found to decrease iron absorption and metabolism (Peraza et al., 1998). In a recent study of herbal samples collected in India (Ernst, 2002), significant amounts of toxic metals were found; the percentages of samples with toxic metals were 64 for lead, 64 for mercury, 41 for arsenic, and 9 for cadmium. Cadmium was detected in three of the preparations in this study; the highest intake of $0.01 \mathrm{mg} /$ day in Madam Catherine, and the lowest of $0.004 \mathrm{mg} /$ day found in Adutwumwaa and Top tonic. Lead was found at a level of $0.04 \mathrm{mg} /$ day in two (Amingya and Madam Catherine) out of the ten herbal tonics studied (Table 2). The potential of exposure to these toxic metals from this work, compared with the provisional tolerable daily intake values of $0.06 \mathrm{mg} /$ day and $0.21 \mathrm{mg} /$ day for cadmium and lead respectively (FAO/WHO, 1993) shows that if taken as recommended by the manufacturers, most of the herbal products would not significantly contribute to exposure of cadmium and lead, while those with these metals cannot reach toxicity levels.

Attempt at exploring the possible uniqueness of physical parameters as a means of standardization ("finger-print") of tonics is shown in the preliminary results presented in Table 4 . The $\mathrm{pH}$ measurement (Table 4) gave a range of $2.0-8.0$; five of the herbal tonics Adutwumwaa, Blowman, Hayaat, Madam Catherine and Mighty Power tonics studied were found to be outside the recommended acceptable $\mathrm{pH}$ limits of herbal preparations for internal use, which is $4.0-7.0$ (Ministry of Health, 2004). The two over the counter irons supplements Supervitone and Vatalife tonic were also found to be outside the recommended acceptable $\mathrm{pH}$ range.

The comparatively high salinity for Hayaat and Madam Catherine (Table 4) suggests the likely high concentration of sodium ions in these products, which hypertensive patients should be mindful of.

Different batches of the same herbal tonic appeared to have the same UV $\lambda_{\max }$ but the other physical parameters were found to be the same 
Table 4: Physical properties of the blood tonics

\begin{tabular}{|c|c|c|c|c|c|c|}
\hline Sample & Batch № & Sal. & $\begin{array}{l}\text { TDS } \\
\mathrm{mg} / \mathrm{l}\end{array}$ & $\begin{array}{l}\text { Temp } \\
{ }^{\circ} \mathrm{C}\end{array}$ & pH & UV Measurements (nm \\
\hline Abrewa Beboboงl & $\mathrm{O} 2$ & 5.5 & 403 & 24.1 & 6.7 & $190,200^{*}$ \\
\hline Adutwumuwaa & $00 / 02$ & 2.4 & 202 & 23.5 & 3.7 & $180,190,197^{*}$ \\
\hline Amingya & 3 & 4.2 & 321 & 23.5 & 6.2 & $196^{*}, 274$ \\
\hline Blowman Tonic & F30048 & 4.7 & 466 & 26.4 & 3.7 & $202 *$ \\
\hline Class Tonic & $\mathrm{T} 11 / 11 / \mathrm{MX} 3$ & 3.4 & 261 & 25.0 & 6.1 & $190,201 *$ \\
\hline Class Tonic & T6/03/MX3 & 6.1 & 527 & 24.1 & 6.2 & $190,201 *$ \\
\hline Fralena & 1003FHP03 & 4.9 & 336 & 23.6 & 5.9 & $109,197^{*}, 222$ \\
\hline Fralena & 1006FHP03 & 5.7 & 398 & 25.2 & 6.2 & $109,197^{*}, 222$ \\
\hline Hayaat & 101 & 24.7 & 1821 & 24.1 & 8.0 & $190,192 *, 207,220$ \\
\hline Madam Catherine & 03-Apr & 18.2 & 1280 & 24.4 & 8.0 & $196^{*}, 222,282$ \\
\hline Madam Catherine & 03-Sep & 18.4 & 1421 & 23.7 & 7.5 & $196^{*}, 222,282$ \\
\hline Mighty Power & DVL00106 & 1.1 & 413 & 23.8 & 2.0 & $194,212,224,281^{*}, 300$ \\
\hline Mighty Power & DVL00105 & 1.2 & 513 & 25.2 & 2.1 & $194,212,224,281^{*}, 300$ \\
\hline Supervitone $^{+}$ & 845703 & 2.7 & 1159 & 25.1 & 3.9 & $199^{*}, 222,230,280$ \\
\hline Supervitone $^{+}$ & 745703 & 2.7 & 391 & 25.2 & 2.5 & $199^{*}, 222,230,280$ \\
\hline Top Tonic & 103 & 4.6 & 352 & 24.8 & 4.3 & $190,200^{*}$ \\
\hline Vitalife Tonic $^{+}$ & V201 & 8.3 & 739 & 23.5 & 3.2 & $197 *, 255$ \\
\hline
\end{tabular}

only in few instances (Table 4). These might be due to poor quality control measures during formulation and processing of the tonics or the different sources of wild-harvested plant raw materials in the formulation. Generally, the constituents of herbal preparations and quality have been found to be influenced by factors such as the genetics of the herbs, the use of fresh plants, temperature, light exposure, water availability, nutrients, period and time of collection, drying, packaging, storage and transportation of raw material, age and part of the plant collected, method of extraction and contamination with microorganisms, heavy metals, pesticides, among others (Calixto, 2000).

\section{CONCLUSION}

The maximum estimated intakes of the ten (10) commonly advertised/used herbal blood tonics studied are not more than $2.2 \mathrm{mg} / \mathrm{day}$, compared with the RDI of $10-15 \mathrm{mg} /$ day and the $150-200$ $\mathrm{mg}$ /day required for the treatment of iron deficiency anaemia. Consequently, the intake of iron supplements might be appropriate for the users of these herbal tonics in the treatment of iron deficiency anaemia. These Ghanaian herbal tonics also appear to be poor sources of essential elements $(\mathrm{Mg}, \mathrm{Cu}, \mathrm{Zn}$ and $\mathrm{Mn}$ ) studied. Cadmium (Cd) was detected in Adutwumwaa, Madam Catherine and Top tonic, while lead $(\mathrm{Pb})$ was detected in Amingya iron tonic and Madam Catherine; but the levels of these toxic metals found will not exceed the recommended safety standard if manufacturer's dosages are adhered to. The different batches of the same tonic were found to be comparable only in trace metals composition and UV $\lambda_{\max }$ values.

\section{ACKNOWLEDGEMENT}

Technical assistance by Emmanuel Davis Afedzi and Daniel Kyinakwa final year Chemistry stu- 
dents, KNUST, Kumasi (May, 2004), Mr. K. Adepa, Technician and Mr. Ray Bright Voegborlo, Lecturer, Department of Chemistry, KNUST, Kumasi Ghana are gratefully acknowledged.

\section{REFERENCES}

Abou-Arab, A. A. K., Kawther, M. S., El Tantawy, M. E., Badeaa, R. I. and Khayria, N. (1999). "Quantity estimation of some contaminants in commonly used medicinal plants in the Egyptian market". Food Chemistry 67:357-363.

ACC/SCN (2001). What Works? A Review of the Efficacy and Effectiveness of Nutrition Interventions. Allen L. H. and Gillespie. S. R. ACC/SCN: Geneva in collaboration with the Asian Development Bank, Manila.

Ajasa, A. O., Bello, M. O., Ibrahim, A. O., Ogunwnade, I. A. and Olawore, N. O. (2004). "Heavy trace metals and macronutrients status in herbal plants of Nigeria". Food Chemistry 85:67-71.

Calixto, J. B. (2000). "Efficacy, safety, quality control, marketing and regulatory guidelines for herbal medicines (phytotherapeutic agents)". Brazilian Journal of Medical and Biological Research 33:179-189.

De Smet, A. G. M. (1999). "Overview of herbal quality control". Drug Information Journal 33:717-724.

Dharmananda, S. (2003). "Iron deficiency anemia. Institute for Traditional Medicine, Portland, OR". http://www.itmonline.org/arts/non -htm. (Accessed: August 24, 2007).

Divrikli, U., Horzum, N., Soylak, M. and Elci, L. (2006). "Trace heavy metal content of some species of herbal plants from Western Anatoli, Turkey". International Journal of Food Science and Technology 41:712-716.

Ernst, E. (2002). "Heavy metals in traditional Indian remedies". European Journal of Clinical Pharmacology, 57(12): 891 -896.
FAO/WHO, (1993). Evaluation of certain food additives and contaminants. $41^{\text {st }}$ Report of the Joint FAO/WHO Expert Committee on Food Additives. World Health Organization Technical Report series 837. Sydney: World Health Organization.

Ghana Demographic and Health Survey 2003 (2004). Calverton, Maryland; Ghana Statistical Service (GSS), Noguchi Memorial Institute for Medical Research (NMIMR), and ORC Macro.

Godt, J., Grosse-Siestrup, F. C., Esche, Brandenburg, P., Reich, A.and Groneberg, D. A. (2006). "The toxicity of cadmium and resulting hazards for human health"

Journal of Occupational Medicine and Toxicology, 1:22.

Hegarty, M. P. and Hegarty, E. E. (2001). "Summary of report, Food Safety of Australian Plant Bushfood" Rural industries Research and Development Corporation (RIRDC) Publication 01/28 AGP-1A.

Hamilton, J. D. and O'Flaherty, E. J, (1995). "Influence of lead on mineralization during bone growth". Fundam. Appl. Toxicol. 26: $256-271$.

Ivery. M. and Elmen, G. (1986). Nutritional Supplements, Minerals and Vitamins Production in a Handbook of Non Prescription Drugs $8^{\text {th }}$ ed. American Pharmaceutical Association. Washington D. C.

Kabelitz, L. (1998). "Heavy Metals in Herbal Drugs". The European Journal of Herbal Medicine. 4(1): 25-33.

Kapoor, R. Methu, U. Kim, H. M. Lee, E. H., and Moon, Y. N. (1993). "Spirulina : Plant" Foods Hum. Nutr. 44(1): 29-34.

Leśniewicz, A., Jaworska, K. and Źyrnicki, W. (2006). "Macro- and micro-nutients and their bioavailabiliy in Polish herbal medicaments". Food Chemistry, 99(4): 670-679. 
Ministry of Health (Ghana National Drug Programme) (2004). Ghana Manual of Harmonised Procedures for Assessing the Safety, Efficacy and Quality of Plant Medicines in Ghana. Ghana.

Okochi, V. I., Okpuzor, J. and Alli, L. A. (2003). "Comparison of an African herbal formular with commercially available haematinics". Afri. J. Biotechnol. 2(8) :237-240.

Peraza, M. A., Ayala-Fierro, F., Barber, D. S., Casarea, E. and Rael, L. T. (1998). "Effects of micronutients on metal toxicity". Environmental Health Perspectives 106 (suppl. 1): 203-216.

Prasad, A. D. (1995). “Zinc: An overview”. $\mathrm{Nu}$ trition 11:93-99.

Serfer-Armah, Y., Nyarko, B. J. B., Akaho, E, H. K., Kyere, A. W. K., Osae, S. and OppongBoachie, K. (2002). "Multielemental analysis of some traditional plant medicines used in Ghana”. Journal of Trace and Microprobe Techniques, 20(3): 419-427.
Tetteh, A. (1997). "Haematological and histological studies on rabbits on Madam Catherine Blood Tonic". Journal of University of Science and Technology 17:20-23.

Varitika, R., Poonam, K., Sayyada, K., Rawat, A.K.S. and Shantan, M. (2001). "Heavy metal accumulation in some herbal drugs". Pharmaceutical Biology, 39(5) 384-387.

Wardlaw, G. M. (1999). Perspective in Nutrition, $4^{\text {th }}$ ed. Boston, WCB/McGraw-Hill, pp. 503534.

West, C. E. (1996). "Strategies to control nutritional anaemia". American Journal of Clinical Nutrition 64:789-791.

WHO (2000) Malnutrition, the Global Picture. Geneva, WHO.

Yip, R. and Dallman, P. R. (1996) Iron. In: Ziegler, E. E., Filer L. J. "Present Knowledge in Nutrition" Washington, DC., ILSI Press. 